\title{
PENGARUH PENAMBAHAN TEPUNG KACANG MERAH TERHADAP SIFAT KIMIA DAN HEDONIK BERAS ANALOG BERBAHAN DASAR UMBI GANYONG (CannaedulisKer.)
}

\author{
Salma Salsabila1*, Antonius Hintono', Bhakti Etza Setiani' \\ ${ }^{1}$ Program Studi Teknologi Pangan, Universitas Diponegoro, Indonesia \\ Co-author: 12salmasalsabila@gmail.com
}

Paper Information
History:
Received : 07-08- 2020
Accepted : 19-09-2020

Keywords:

Rice Analog

Ganyong

Red Bean

\begin{abstract}
Abstrak: Beras analog merupakan beras tiruan dengan bahan baku tepung non beras yang mengandung gizi dan kenampakan menyerupai beras padi. Beras analog kali ini menggunakan bahan baku umbi ganyong sebagai sumber karbohidrat dan kacang merah untuk memperbaiki nilai gizi dan kenampakan beras analog. Penelitian ini bertujuan untuk mengetahui pengaruh penambahan tepung kacang merah pada beras analog berbahan dasar umbi ganyong terhadap kadar air, serat kasar, protein dan hedonik. Penelitian ini terdiri dari formulasi yang dibagi menjadi 4 perlakuan berupa penambahan tepung kacang merah dengan konsentrasi $0 \%, 5 \%, 10 \%$, dan $15 \%$. Variabel yang diamati adalah kadar air, serat kasar, protein, dan hedonik. Hasil penelitian menunjukkan bahwa penambahan tepung kacang merah dengan berbeda konsentrasi memberikan pengaruh nyata $(P<0,05)$ dalam meningkatkan kadar air, serat kasar, protein, dan memperbaiki rasa, tekstur, dan kepulenan beras analog. Hasil penelitian menunjukan konsentrasi penambahan tepung kacang merah terbaik yaitu $15 \%$ yang menghasilkan kadar air7,76 $\pm 0,152 \%$, serat kasar 3,01 $\pm 0,068 \%$, dan protein $7,41 \pm 0,038 \%$.
\end{abstract}

\begin{abstract}
Analog rice is artificial rice product made from non rice raw material which contains nutrients and looks like padi rice. This research using raw material such as umbi ganyong as source of carbohydrates and red bean to improve the nutritional value and appearance of analog rice. The purpose of this research was to study the concentration effect ofred bean flour added into on rice analog made from umbiganyong(ganyong root) toward water content, raw fiber,protein, and hedonic. The treatments applied were To for $0 \%$ concentration, T1 for 5\% concentration, T2 for 10\% concentration, and T3 for 15\% concentration. The observed variables were water content, protein, crudefiber, and preference level. The result of the study showed that the addition of red bean flourwith various concentrationsreveals the difference $(p<0,05)$ in rising water content, crudefiber,protein and improving taste, texture, and rice analogfluffiness. The outcome of the research pointed that the recommendation of red bean flour added into analog rice was at $15 \%$ which were resulting water content $7,76 \pm 0,152 \%$, crudefiber of $3,01 \pm 0,68 \%$, and protein $7,41 \pm 0,038 \%$
\end{abstract}

\section{A. LATAR BELAKANG}

Beras analog merupakan beras tiruan yang dibuat dengan bahan baku tepung non beras yang mengandung gizi menyerupai atau melebihi daripada beras padi (Noviasari et al., 2013). Beras analog dirancang dengan tujuan untuk diversifikasi pangan agar mengurangi ketergantungan pangan pada konsumsi beras padi. Beras analog membutuhkan bahan yang mengandung karbohidrat sebagai kandungan yang mendukung dua proses dalam pembuatan yaitu granulasi dan ekstrusi (Srihari et al., 2016). Salah satu sumber pangan yang dapat dijadikan beras analog yaitu umbi, khususnya pada penelitian kali ini yaitu umbi ganyong. Selain kandungan karbohidratnya, umbi ganyong memiliki keunggulan diantara umbi lain yaitu kandungan besi, fosfor, dan kalsium yang tinggi (Kusbandari, 2015). Namun dari segi protein dan serat kasar pada umbi ganyong tergolong masih rendah sehingga diperlukan bahan tambahan untuk menutupi kekurangan tersebut. Umbi ganyong mengandung protein yang tergolong masih rendah yaitu sebesar $1 \mathrm{~g} / 100 \mathrm{~g}$. Oleh sebab itu diperlukan penambahan bahan pangan yang mengandung protein dan serat kasar yang tinggi seperti kacang-kacangan. Salah satu kacang-kacangan yang mengandung gizi tinggi yaitu kacang merah (Phaseolus vulgaris L.) sebab kandungan protein dan serat kasarnya tinggi yaitu protein $23,58 \%$ dan serat kasar 24,9\% setiap 100 gramnya (Astuti, 2013). Kadar protein pada kacang merah sebesar 22,3 g/100 g berat kering (Astawan, 2009).

Protein berfungsi sebagai zat pembangun, pembentuk jaringan baru serta memperbaiki jaringan yang rusak pada tubuh (Ernawati, Prihatini and Yuriestia, 2016). Serat kasar terdiri dari selulosa, hemiselulosa, dan lignin yang berfungsi sebagai pengganjal rasa kenyang dan mempersingkat proses 
pencernaan di dalam tubuh (Prawitasari, Ismadi and Estiningdriati, 2012). Penerimaan konsumen juga perlu ditinjau dari parameter warna, aroma, rasa, tekstur, kepulenan dan overall agar konsumen tertarik untuk mengkonsumsi. Penambahan tepung kacang merah dianggap dapat memperbaiki rasa serta tekstur beras analog setelah beras analog ditanak. Penambahan kacang merah akan meningkatkan cita rasa nasi dari beras analog (Astuti, S. and Anayuka, 2019). Pada umumnya masyarakat Indonesia menyukai nasi dengan tekstur pulen. Amilopektin akan mempengaruhi tingkat kepulenan nasi apabila amilopektin lebih tinggi daripada amilosa maka nasi akan cenderung pulen (Adicandra and Estiasih, 2016). Teknologi ekstrusi dibutuhkan dalam proses pembuatan beras analog sebab proses pengaliran, pencampuran, pengadonan, pemanasan, dan pencetakan menghasilkan beras analog yang berbentuk mirip dengan beras padi (Budi et al., 2013).

Penelitian ini bertujuan mengetahui pengaruh penambahan tepung kacang merah terhadap peningkatan kadar air, serat kasar, protein, memperbaiki karakteristik fisik aroma, warna, rasa, tekstur, kepulenan dan overall, serta mengetahui formulasi terbaik beras analog agar menciptakan pangan fungsional berbasis pangan lokal.

\section{B. METODE PENELITIAN}

\section{Tempat Penelitian}

Penelitian telah dilaksanakan pada bulan MaretMei 2020 di Griya Ketelaqu Gunung Pati, Semarang; untuk proses pembuatan tepung umbi ganyong dan tepung kacang merah; Technopark Pangan Dinas Ketahanan Pangan Kabupaten Grobogan untuk pembuatan dan pencetakan beras analog; Laboratorium Balai Pengkajian Teknologi Pertanian Ungaran, Jawa Tengah untuk pengujian proksimat parameter kadar air, protein, dan serat kasar.

\section{Rancangan Penelitian}

Rancangan yang digunakan dalam penelitian ini adalah Rancangan Acak Lengkap (RAL) yang terdiri dari 4 perlakuan.

$\mathrm{T} 0=$ kosentrasi penambahan kacang merah $0 \%$

$\mathrm{T}_{1}=$ konsentrasi penambahan kacang merah $5 \%$

$\mathrm{T}_{2}=$ konsentrasi penambahan kacang merah $10 \%$

$\mathrm{T}_{3}=$ konsentrasi penambahan kacang merah $15 \%$ Formulasi perlakuan penambahan tepung kacang merah beras analog umbi ganyong dapat dilihat padaTabel 1.

Tabel 1.

Formulasi Perlakuan Penambahan Tepung Kacang Merah Pada Beras Analog Umbi Ganyong

\begin{tabular}{|c|c|c|c|c|}
\hline Material & To & T1 & T2 & T3 \\
\hline Tepung Umbi Ganyong(\%) & 60 & 60 & 60 & 60 \\
\hline Tepung Kacang Merah (\%) & o & 5 & 10 & 15 \\
\hline GMS (\%) & 1 & 1 & 1 & 1 \\
\hline Air (\%) & 39 & 39 & 39 & 39 \\
\hline
\end{tabular}

\section{Alat dan Bahan Penelitian}

Alat yang digunakan dalam penelitian ini adalah Kompor, Panci, Pisau, Slicer umbi tipis, Grinder, Cabinet dryer, Saringan mesh 100, dan Extruder pencetak beras analog.

Bahan yang digunakan dalam penelitian ini adalah tanaman umbi ganyong berumur tua (5-10 bulan) sebanyak $50 \mathrm{~kg}$ diperoleh dari Muria, Kudus, Jawa Tengah, tanaman kacang merah berumur tua dengan keadaan segar sebanyak $2 \mathrm{~kg}$ di pasar lokal Semarang, dan GMS (Glycerol Monostearate).

\section{Cara Kerja}

\subsection{Pembuatan Tepung Umbi Ganyong}

Pembuatan tepung umbi ganyong mengacu pada pendapat (Richana and Sunarti, 2004) yang telah dimodifikasi yaitu umbi ganyong disortir kemudian dikupas dan dicuci dengan air mengalir. Setelah itu umbi ganyong diiris tipis dengan slicer dan direndam agar getah yang melekat hilang kemudian dicuci bersih kembali. Irisan umbi ganyong dikeringkan dengan cabinet dryer bersuhu $60^{\circ} \mathrm{C}$ selama 12 jam. Umbi ganyong yang sudah kering di grinder dan diayak dengan saringan 100 mesh agar ukuran butir seragam.

\subsection{Pembuatan Tepung Kacang Merah}

Pembuatan tepung kacang merah mengacu pada (Rakhmawati, Amanto and Praseptiaga, 2014) yang telah dimodifikasi yaitu kacang merah dicuci bersih dan direndam dalam air suhu kamar selama 24 jam. Kacang merah yang telah direndam dicuci kemudia dikukus selama 20 menit dengan api sedang. Kacang merah yang telah dikukus dijemur dibawah sinar matahari selama 3 hari. Kacang merah yang sudah kering digrinder dan diayak dengan saringan 100 mesh agar ukuran seragam dan halus.

\subsection{Pembuatan Beras Analog}

Pembuatan beras analog mengacu pada pendapat (Noviasari et al., 2013) yang telah dimodifikasiyaitu terdapat 4 perlakuan yang ditetapkan yaitu $\mathrm{T}_{0}=$ tanpa penambahan tepung kacang merah, $\mathrm{T}_{1}=$ penambahan tepung kacang merah $5 \%$, T22= penambahan tepung kacang merah $10 \%$, dan $\mathrm{T}_{3}=$ penambahan tepung kacang merah $15 \%$. Setiap perlakuan diberi GMS (Glycerol Monostearat) sebagai emulsi sebesar 1\% dan air 39\% total bahan utama 500 gram tanpa penambahan tepung kacang merah sebanyak 20 sampel. Bahan dicampur hingga pulen kemudian dikukus 15 menit dan dimasukan ke single screw hot extruder kecepatan ulir $40 \mathrm{~Hz}$, kecepatan pisau $20 \mathrm{~Hz}$, dan bersuhu $60^{\circ} \mathrm{C}$. Beras analog yang keluar dari pencetak dikeringkan dibawah sinar matahari agar kering hingga bagian dalam selama 24 jam. 


\subsection{Pengujian Kadar Air}

Pengujian kadar air mengacu (Anggraeni, Darmanto et al., 2019) yaitu kadar air merupakan kandungan air bahan yang dinyatakan berdasarkan berat basah dan berat kering yang prinsip pengujiannya yaitu menguapkan air yang terkandung pada suatu bahan menggunakan oven atau cabinet dryer kemudian kehilangan berat bahan diukur yang menjadikan hal tersebut disebut sebagai kadar air.Setelah itu sampel didinginkan dengan desikator \pm 30 menit lalu ditimbang.

\subsection{Pengujian Kadar Protein}

Prinsip penentuan protein menurut metode Kjeldahl yaitu oksidasi senyawa organik oleh asam sulfat agar membentuk $\mathrm{CO}_{2}$ dan $\mathrm{H}_{2} \mathrm{O}$ kemudian terjadi pelepasan nitrogen dalam bentuk ammonia, jumlah nitrogen tersebut yang menentukan besarnya kandungan protein (Bakhtra, Rusdi and Mardiah, 2016).Hasil destilat dengan $\mathrm{HCl} 0,2 \mathrm{~N}$ hingga dari hijau berubah menjadi abu-abu netral.

\subsection{Pengujian Serat Kasar}

Prinsip penentuan serat kasar menurut metode Gravimetri yaitu ekstraksi lemak, protein, karbohidrat kemudian akan tersisa serat kasar yang akan ditimbang hingga berat konstannya. Residu bersamaan dengan kertas saring dikeringkan hingga bobot menjadi konstan lalu ditimbang dan dihitung.

\subsection{Uji Hedonik}

Uji hedonik mengacu pada (Andriani, Ansharullah and Asyik, 2018) yaitu sebanyak 4 sampel yang telah diberi kode meliputi perlakuan $\mathrm{T}_{0}, \mathrm{~T}_{1}, \mathrm{~T}_{2}$, dan $\mathrm{T}_{3}$ diberikan kepada 25 panelis semi terlatih. Parameter yang ditetapkan meliputi warna, rasa, aroma, tekstur, dan overall dengan skala $1=$ sangat tidak suka, $2=$ tidak suka, $3=$ biasa saja, $4=$ suka, dan $5=$ sangat suka. penilaian yang dilakukan panelis ditulis pada kolom kode sampel dengan sala yang telah ditetapkan.

\subsection{Pengolahan dan Analisis Data}

Data uji kadar air, serat kasar, dan protein dianalisis statistik dengan menggunakan uji parametrik Analysis of Variance (ANOVA). Analisis data dilakukan dengan menggunakan aplikasi SPSS 22.0 statistic software dengan taraf signifikansi 5\%. Adanya pengaruh antar perlakuan dilanjutkan dengan Uji Wilayah Berganda Duncan. Uji hedonik dianalisismenggunakan uji non parametrik Kruskal Wallis dengan aplikasi SPSS 22.0 dan adanya pengaruh antar perlakuan dilanjutkan dengan Uji Mann Whitney.

\section{HASIL DAN PEMBAHASAN}

Metode yang telah dirancang diaplikasikan pada penelitian ini menghasilkan beras analog dengan empat perlakuan yang dapat dilihat pada kenampakan seperti Gambar 1.
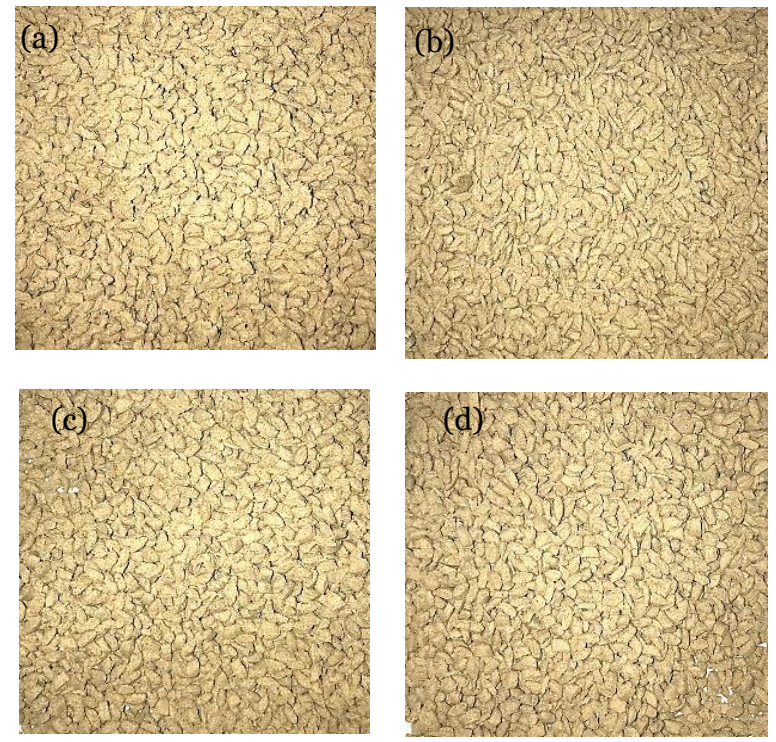

Gambar 1. Beras analog berbagai perlakukan: (a). To (o\%); (b). T1 (5\%); (c). T2 (10\%); (d). T3 (15\%)

\section{Sifat Kimia Beras Analog}

\subsection{Kadar Air}

Hasil pengujian kadar air beras analog umbi ganyong dengan penambahan tepung kacang merah dengankonsentrasi yang berbeda disajikan pada Tabel 2.

Tabel 2.

Kadar Air Beras Anlaog Umbi Ganyong Dengan Penambahan Tepung Kacang Merah

\begin{tabular}{cc}
\hline Perlakuan & Kadar Air (\%) \\
\hline $\mathrm{T}_{\mathrm{o}}$ & $6,68 \pm 0,13 \mathrm{O}^{\mathrm{a}}$ \\
$\mathrm{T}_{1}$ & $6,92 \pm 0,084^{\mathrm{b}}$ \\
$\mathrm{T}_{2}$ & $7,28 \pm 0,084^{\mathrm{c}}$ \\
$\mathrm{T}_{3}$ & $7,76 \pm 0,152^{\mathrm{d}}$ \\
\hline
\end{tabular}

a-d Superscript huruf kecil yang berbeda pada kolom kadar air menunjukkan perbedaan nyata $(\mathrm{p}<0,05)$. $\mathrm{T}_{0}=0 \% ; \mathrm{T}_{1}=5 \% ; \mathrm{T}_{2}=10 \% ;$ dan $\mathrm{T}_{3}=15 \%$

Berdasarkan Tabel 2, penambahan tepung kacang merah pada beras analog umbi ganyong, setelah dilakukan pengolahan data menggunakan ANOVA menunjukkan pengaruh nyata $(\mathrm{p}<0,05)$ terhadap kadar air beras analog dengan rata-rata sebesar $6,68 \%$ (o\% tepung kacang merah), 6,92\% (5\% tepung kacang merah), 7,28 \% (10\% tepung kacang merah) dan $7,76 \%$ (15\% tepung kacang merah).

Berdasarkan data Tabel 2 diketahui semakin tinggi konsentrasi penambahan tepung kacang merah maka kadar air beras analog ikut meningkat. Penambahan kacang merah meningkatkan kadar air yang diindikasikan semakin meningkatnya kandungan serat kasar. Hal ini sesuai dengan pendapat (Andriani, Ansharullah and Asyik, 2018) yang menyatakan bahwa terdapat gugus hidroksil bebas bersifat 
polar pada serat sehingga air yang terikat di dalam serat sulit dilepas meskipun melibatkan pemanasan oleh sebab itu kemampuan mengikat dan menyerap air pada pangan akan meningkat. Kadar air seluruh perlakuan yang ditetapkan pada penelitian beras analog berbahan dasar umbi ganyong kurang dari $14 \%$ sehingga sesuai dengan SNI kadar air pada beras. Hal tersebut sesuai dengan pendapat dari (Srihari et al., 2016) yang menyatakan kadar air yang aman untuk beras analog sesuai dengan SNI 6128:2008 kadar air beras yaitu <14\% agar mencegah pertumbuhan kapang.

Pengeringan mampu menurunkan kadar air pada beras analog. Suhu yang digunakan pada saat pengeringan yaitu $60^{\circ} \mathrm{C}$ yang merupakan suhu optimum pemanasan pada beras analog. Apabila suhu yang digunakan terlalu tinggi dikhawatirkan mempengaruhi kadar air yang terkandung dalam panganmenjadikan beras analog menjadi keras dan kehilangan gizi. Hal ini sesuai dengan pendapat (Mentari, Anandito and Basito, 2016) yang menyatakan bahwa suhu tinggi akan meningkatkan denaturasi protein menyebabkan kadar air akan turun. Perlakuan yang paling efektif yaitu perlakuan $\mathrm{T}_{3}$ sebab selain kadar air yang sesuai dengan SNI, perlakuan T3 diindikasikan dari penjelasan sebelumnya akan ikut meningkatkan kadar protein dan serat beras analog berbahan dasar umbi ganyong.

\subsection{Protein}

Hasil pengujian protein beras analog umbi ganyong dengan penambahan tepung kacang merah pada konsentrasi yang berbeda disajikan pada Tabel 3 .

Tabel 3.

Kadar Protein Beras Anlaog Umbi Ganyong Dengan Penambahan Tepung Kacang Merah

\begin{tabular}{cc}
\hline Perlakuan & Protein $(\%)$ \\
\hline $\mathrm{T}_{\mathrm{o}}$ & $4,29 \pm 0,048^{\mathrm{a}}$ \\
$\mathrm{T}_{1}$ & $5,54 \pm 0,03 \mathrm{0}^{\mathrm{b}}$ \\
$\mathrm{T}_{2}$ & $6,35 \pm 0,138^{\mathrm{c}}$ \\
$\mathrm{T}_{3}$ & $7,41 \pm 0,038^{\mathrm{d}}$ \\
\hline
\end{tabular}

${ }^{\mathrm{a}-\mathrm{d}}$ Superscript huruf kecil yang berbeda pada kolom kadar protein menunjukkan perbedaan nyata $(\mathrm{p}<0,05) . \mathrm{T}_{0}=0 \% ; \mathrm{T}_{1}=5 \% ; \mathrm{T}_{2}=10 \%$; dan $\mathrm{T}_{3}=15 \%$

Berdasarkan Tabel 3, penambahan tepung kacang merah pada beras analog umbi ganyong, setelah dilakukan pengolahan data menggunakan ANOVA menunjukkan pengaruh nyata $(\mathrm{p}<0,05)$ terhadap protein beras analog dengan rata-rata sebesar4,29\% (o\% tepung kacang merah), 5,54\% (5\% tepung kacang merah), 6,35\% (10\% tepun gkacang merah) dan7,41\% (15\% tepung kacang merah).

Pada Tabel 3 diketahui bahwa penambahan tepung kacang merah dalam pangan akan meningkatkan kandungan protein di dalamnya. Pada perlakuan $\mathrm{T}_{3}$ dengan penambahan tepung kacang merah $15 \%$ diketahui kandungan protein telah memenuhi standar protein beras padi yaitu berkisar $7 \%$. Hal ini sesuai dengan pendapat (Masniawati et al., 2012) yang menyatakan kadar protein beras berada pada kisaran $7 \%$.

Semakin tinggi penambahan tepung kacang merah pada beras analog, semakin tinggi kadar air sebab protein juga ikut meningkat mengingat pada kacang merah mengandung protein yang tinggi. Hal ini sesuai dengan pendapat (Mentari, Anandito and Basito, 2016) yang menyatakan bahwa semakin meningkatnya kadar protein maka air yang terikat semakin tinggi. Protein memiliki struktur yang mampu mengikat molekul air sehingga penambahan tepung kacang merah pada beras analog dapat mempengaruhi peningkatan kadar air. Hal ini sesuai dengan pendapat (Trisnawati and Nisa, 2015) yang menyatakan bahwa gugus fungsional $(\mathrm{NH} 2, \mathrm{NH}, \mathrm{OH}, \mathrm{CO})$ di dalam struktur protein akan mengikat molekul air melalui ikatan hidrogen.

Pembuatan beras analog berbahan dasar umbi ganyong dengan penambahan tepung kacang merah melibatkan proses pemasakan dan suhu tinggi dengan mekanisme yang sama setiap perlakuan. Suhu tinggi dapat mempengaruhi kandungan protein pada beras analog. Hal tersebut sesuai dengan pendapat (Mentari, Anandito and Basito, 2016) yang menyatakan suhu tinggi akan mempengaruhi kelarutan atau solubilitas protein sebab meningkatkan denaturasi pada protein. Penggunaan suhu $60^{\circ} \mathrm{C}$ pada proses pengeringan tepung umbi ganyong dan tepung kacang merah sudah tepat sebab apabila suhu terlalu tinggi akan menyebabkan semakin tinggi kerusakan pada protein. Hal ini sesuai dengan pendapat (Naga et al., 2010) yang menyatakan bahwa suhu $60^{\circ} \mathrm{C}$ merupakan suhu optimum pemanasan untuk mencegah koagulasi protein, apabila suhu berlebih akan menyebabkan kerusakan atau denaturasi protein. Dari penjelasan sebelumnya diketahui bahwa kadar protein dalam beras padi berkisar $7 \%$. Sehingga dapat diketahui bahwa perlakuan paling efektif dalam peningkatan kadar protein dalam beras analog yaitu perlakuan $\mathrm{P}_{3}$ dengan kadar protein sebesar $7,41 \pm 0,038 \%$ dengan penambahan tepung kacang merah $15 \%$ 


\subsection{Serat Kasar}

Hasil pengujian serat kasarberas analog umbi ganyong dengan penambahan tepung kacang merah pada konsentrasi yang berbeda disajikan pada Tabel 4.

Tabel 4.

Kadar Serat Kasar Beras Anlaog Umbi Ganyong Dengan Penambahan Tepung Kacang Merah

\begin{tabular}{cc}
\hline Perlakuan & Serat Kasar(\%) \\
\hline $\mathrm{T}_{\mathrm{o}}$ & $2,15 \pm 0,044^{\mathrm{a}}$ \\
$\mathrm{T}_{1}$ & $2,32 \pm 0,027^{\mathrm{b}}$ \\
$\mathrm{T}_{2}$ & $2,45 \pm 0,042^{\mathrm{c}}$ \\
$\mathrm{T}_{3}$ & $3,01 \pm 0,068^{\mathrm{d}}$ \\
\hline
\end{tabular}

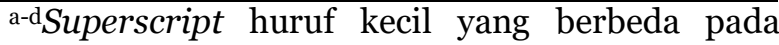
kolom kadar serat kasar menunjukkan perbedaan nyata $(\mathrm{p}<0,05) . \mathrm{T}_{0}=0 \% ; \mathrm{T}_{1}=5 \% ; \mathrm{T}_{2}=10 \%$; dan $\mathrm{T}_{3}=15 \%$

Berdasarkan Tabel 4, penambahan tepung kacang merah pada beras analog umbi ganyong, setelah dilakukan pengolahan data menggunakan ANOVA menunjukkan pengaruh nyata $(\mathrm{p}<0,05)$ terhadap serat kasarberas analog dengan rata-rata sebesar 2,15\% ( $0 \%$ tepung kacang merah), 2,32\% (5\% tepung kacang merah), 2,45\% (10\% tepung kacang merah) dan 3,01\% (15\% tepung kacang merah). Makanan yang mengandung serat tinggi akan lebih mudah dicerna oleh tubuh. Hal tersebut sesuai dengan pendapat (Mahar Maligan, Dian Pratiwi and Dewanti Widyaningsih, 2019) yang menyatakan bahwa serat tinggi akanmenyebabkan makanan cepat untuk dicerna dan dikeluarkan sehingga meningkatkan kesehatan pencernaan. Seluruh proses pembuatan tepung kacang merah pada penelitian ini menggunakan mekanisme yang sama.
Perendaman saat pembuatan tepung kacang merah dapat mempengaruhi tinggi atau rendahnya serat kasar beras analog.

Pada Tabel 4 diketahui semakin banyak penambahan tepung kacang merah pada beras analog maka semakin tinggi serat kasar. Hal tersebut sesuai dengan pendapat (Mentari, Anandito and Basito, 2016) yang menyatakan bahwa kadar serat kasar pada kacang merah yaitu $3,8 \%$ jauh lebih tinggi dibandingkan beras $(0,2 \%)$ Kacang merah merupakan sumber serat yang tinggi sehingga semakin banyak penambahan tepung kacang merah maka serat kasar yang terkandung dalam beras analog berbahan dasar umbi ganyong ikut meningkat. Hal ini sesuai dengan pendapat (Wahjuningsih, 2019) yang menyatakan bahwa kacang merah mengandung serat yang tinggi yaitu setiap 100 gram tepung kacang merah mengandung 10 gram serat yang terdiri dari serat tidak larut dan serat larut.

Pada penelitian kali ini pembuatan tepung kacang merah dilakukan tanpa membuang kulit arinya sehingga semakin banyak penambahan tepung kacang merah pada beras analog akan semakin tinggi kandungan serat kasar yang terkandung. Dari segi parameter serat kasar, perlakuan yang paling efektif dalam meningkatkan kandungan serat kasar pada beras analog berbahan dasar umbi ganyong yaitu perlakuan $\mathrm{P}_{3}$ dengan penambahan tepung kacang merah $15 \%$.

\section{Sifat Hedonik}

Hasil penelitian sifat hedonik beras analog berbahan dasar umbi ganyong dengan penambahan konsentrasi tepung kacang merah yang berbeda di setiap perlakuan disajikan pada Tabel 5 .

Tabel 5 .

Hasil Analisis Uji Hedonik Beras Analog Umbi Ganyong Dengan Penambahan Tepung Kacang Merah

\begin{tabular}{ccccccc}
\hline \hline Perlakuan & Aroma & Warna & Tekstur & Rasa & Kepulenan & Overall \\
\hline To & $3,32 \pm 0,85$ & $2,84 \pm 0,99$ & $2,44 \pm 0,96^{\mathrm{a}}$ & $2,44 \pm 0,92^{\mathrm{a}}$ & $2,4 \pm, 91^{\mathrm{a}}$ & $2,84 \pm 0,69^{\mathrm{a}}$ \\
$\mathrm{T}_{1}$ & $2,92 \pm 0,81$ & $3,12 \pm 0,78$ & $2,76 \pm 1,05^{\mathrm{ab}}$ & $2,88 \pm 0,726^{\mathrm{ab}}$ & $2,96 \pm 0,68^{\mathrm{b}}$ & $3,28 \pm 0,98^{\mathrm{ab}}$ \\
$\mathrm{T} 2$ & $3,08 \pm 0,76$ & $2,96 \pm 0,68$ & $3,4 \pm 1,19^{\mathrm{bc}}$ & $3,08 \pm 0,86^{\mathrm{bc}}$ & $3,44 \pm 0,71^{\mathrm{c}}$ & $3,48 \pm 0,59^{\mathrm{b}}$ \\
T3 & $3 \pm 0,867$ & $3,12 \pm 1,01$ & $3,68 \pm 1,03^{\mathrm{c}}$ & $3,52 \pm 1,085^{\mathrm{c}}$ & $3,68 \pm 0,69^{\mathrm{c}}$ & $3,68 \pm 0,62^{\mathrm{b}}$ \\
\hline
\end{tabular}

a-d Superscript huruf kecil yang berbeda pada kolom uji hedonik menunjukkan perbedaan nyata $(\mathrm{p}<\mathrm{0}, 05)$. $\mathrm{T}_{0}=0 \% ; \mathrm{T}_{1}=5 \% ; \mathrm{T}_{2}=10 \%$; dan $\mathrm{T}_{3}=15 \%$

Skala hedonik dengan skor 1-5 berturut-turut menyatakan (1) sangat tidak suka, (2) tidak suka, (3) biasa saja, (4) suka, dan (5) sangat suka

\subsection{Aroma}

Berdasarkan Tabel 5 diketahui bahwa panelis tidak dapat membedakan aroma beras analog berbahan dasar tepung umbi ganyong dengan penambahan tepung kacang merah. Hal tersebut menunjukan bahwa penambahan tepung kacang merah pada beras analog umbi 
ganyong tidak berpengaruh nyata $(\mathrm{p}>0,05)$ terhadap aroma. Rentang skala hedonik untuk parameter aroma perlakuan To hingga $\mathrm{T}_{3}$ berkisar antara 2,92-3,32 dengan arah kesukaan yaitu biasa saja. Kacang merah memiliki aroma khas yaitu langu yang dapat membuat konsumen kurang tertarik. Hal tersebut sesuai dengan pendapat (Mentari, Anandito and Basito, 2016) yang menyatakan bahwa kacang merah mengandung enzim lipoksigenase yang menyebabkan aroma langu.

Proses pembuatan tepung kacang merah tanpa pengupasan kulit dapat mencegah timbulnya bau langu pada beras analog. Hal ini sesuai dengan pendapat (Pangastuti, Affandi and Ishartani, 2013) yang menyatakan pengupasan kulit kacang merah menyebabkan meningkatnya asam fitat pada kacang merah sehingga bau langu akan ikut meningkat. Proses pembuatan tepung kacang merah dan beras analog melibatkan proses pengukusan yang mampu mengurangi aroma langu pada kacang merah. Oleh sebab itu berkurangnya aroma langu pada kacang merah yang disebabkan proses pemanasan menyebabkan tidak terdapat pengaruh nyata terhadap penambahan tepung kacang merah pada beras analog umbi ganyong.

\subsection{Warna}

Berdasarkan Tabel 5 diketahui bahwa panelis tidak dapat membedakan warna beras analog berbahan dasar tepung umbi ganyong dengan penambahan tepung kacang merah. Hal tersebut menunjukan bahwa penambahan tepung kacang merah pada beras analog umbi ganyong tidak berpengaruh nyata $(\mathrm{p}>0,05)$ terhadap warna. Rentang skala hedonik untuk parameter warna perlakuan To hingga $\mathrm{T}_{3}$ berkisar antara 2,84-3,12 dengan arah kesukaan yaitu biasa saja.Pengaruh oksidasi pada getah umbi menyebabkan warna pada tepung umbi ganyong berwarna coklat sehingga seluruh beras analog memiliki warna yang hampir mirip dengan dominasi warna coklat. Hal ini sesuai dengan pendapat (Sunyoto, 2017) yang menyatakan oksidasi senyawa-senyawa fenol pada getah umbi menghasilkan senyawa melanoidin yang menyebabkan tepung umbi berwarna kecoklatan.

Perlakuan $\mathrm{T}_{3}$ yaitu perlakuan dengan penambahan tepung kacang merah 15\% merupakan perlakuan yang paling disukai panelis. Hal tersebut disebabkan sumber warna merah pada kacang merah yang memudarkan warna coklat sehingga beras analog berwarna coklat lebih muda. Pada pembuatan tepung umbi ganyong dan kacang merah melibatkan proses pemanasan sehingga terjadi reaksi maillard yang mengakibatkan beras analog semakin berwarna coklat tua. Hal ini sesuai dengan pendapat (Astuti, S. and Anayuka, 2019) yang menyatakan bahwa reaksi maillard terjadi antara gula pereduksi dengan gugus amino bebas dari asam amino bagian protein sehingga membentuk senyawa melanoidin yang berwana coklat.

\subsection{Tekstur}

Berdasarkan hasil pada Tabel 5 diketahui panelis dapat membedakan tekstur beras analog berbahan dasar umbi ganyong dengan penambahan kacang merah. Hal tersebut menunjukan bahwa penambahan tepung kacang merah pada beras analog umbi ganyong berpengaruh nyata $(\mathrm{p}>0,05)$ terhadap tekstur. Rentang skala hedonik untuk parameter tekstur perlakuan To hingga $\mathrm{T}_{3}$ berkisar antara 2,44-3,68 dengan arah kesukaan yaitu tidak suka hingga suka dan perlakuan yang paling disukai yaitu T3.Tepung umbi ganyong mengandung amilopektin yang lebih tinggi dari amilosa yang akan berpengaruh terhadap tekstur beras analog yang telah ditanak. Hal tersebut sesuai dengan pendapat (Harmayani et al., 2012) yang menyatakan kandungan amilopektin pada tepung umbi ganyong lebih tinggi yaitu 50,90\% sedangkan amilosa sebesar $42,49 \%$.

Pada data Tabel 5 perlakuan yang paling disukai ke perlakuan yang paling tidak disukai yaitu $\mathrm{T}_{3}, \mathrm{~T}_{2}$. $\mathrm{T}_{1}$, dan $\mathrm{T}_{0}$. Semakin tinggi penambahan tepung kacang merah membuat tekstur beras analog yang telah ditanak menjadi semakin mengembang dan akan lebih pulen. Hal ini sesuai dengan pendapat (Wahjuningsih and Kunarto, 2013) yang menyatakan bahwa kandungan amilopektin yang tinggi menyebabkan granula pati akan mengembang lebih cepat dan berinteraksi menyerap protein lebih tinggi pada proses gelatinisasi.

\subsection{Rasa}

Berdasarkan data pada Tabel 5 diketahui bahwa panelis mampu membedakan rasa beras analog berbahan dasar tepung umbi ganyong dengan penambahan tepung kacang merah. Hal tersebut menunjukan bahwa penambahan tepung kacang merah pada beras analog umbi ganyong berpengaruh nyata ( $>0,05)$ terhadap rasa. Rentang skala hedonik untuk parameter rasa perlakuan To hingga $\mathrm{T}_{3}$ berkisar antara 2,44-3,52 dengan arah kesukaan yaitu tidak suka hingga suka dan perlakuan yang paling disukai yaitu T3. 
Peningkatan kesukaan terhadap beras analog terjadi seiring dengan semakin tingginya penambahan tepung kacang merah. Umbi ganyong memiliki rasa sedikit getir pahit yang membuat panelis kurang menyukai rasa tersebut sehingga penambahan kacang merah memperbaiki rasa dari beras analog. Hal ini sesuai dengan pendapat (Riskiani et al., 2014) yang menyatakan bahwa umbi ganyong mengandung senyawa fenol dan tannin yang dapat menimbulkan rasa sedikit getir dan pahit. Semakin meningkatnya kandungan kacang merah akan menimbulkan peningkatan terhadap rasa. Hal ini sesuai dengan pendapat (Astuti, S. and Anayuka, 2019)yang menyatakan bahwa kandungan asam amino pada kacang merah akan meningkatkan cita rasa.

\subsection{Kepulenan}

Berdasarkan data Tabel 5 diketahui bahwa panelis dapat membedakan kepulenan beras analog berbahan dasar tepung umbi ganyong dengan penambahan tepung kacang merah. Hal tersebut menunjukan bahwa penambahan tepung kacang merah pada beras analog umbi ganyong berpengaruh nyata ( $>>0,05)$ terhadap kepulenan. Rentang skala hedonik untuk parameter kepulenan perlakuan To hingga T3 berkisar antara 2,4-3,368 dengan arah kesukaan yaitu tidak suka hingga suka dan perlakuan yang paling disukai yaitu T3. Dapat diketahui bahwa semakin meningkatnya kadar tepung kacang merah yang ditambahkan akan semakin disukai panelis. Semakin tinggi kadar tepung kacang merah maka semakin pulen nasi yang dihasilkan sebab penambahan kacang merah meningkatkan amilopektin yang ada di dalam beras analog.

Kandungan protein pada beras analog pada penelitian kali ini memiliki kadar protein dibawah 8,5\%. Hal tersebut sesuai pendapat (Masniawati et al., 2012) yang menyatakan bahwa beras dengan kadar protein lebih kecil dari 8,5\% akan cenderung menghasilkan nasi yang pulen. Pada umumnya masyarakat lebih menyukai nasi dengan tektur pulen. Kepulenan nasi dipengaruhi oleh kandungan amilopektin. Nasi yang memiliki amilopektin tinggi akan bertekstur pulendantetapmenggumpalwalapun nasi sudahdalam kondisi dingin. Hal ini sesuai pendapat (Adicandra dan Estiasih 2016) yang menyatakan beras yang mengandung amilopektin tinggi akan menjadi nasi pulen dan bertekstur lunak walaupun sudah dingin. Hal tersebut didukung oleh pendapat (Maligan et al., 2019) yang menyatakan bahwa beras dengan amilopektin tinggi (rendah amilosa) apabila dimasak akan menghasilkan nasi yang pulen.

\subsection{Overall}

Data Tabel 5 menunjukan bahwa terdapat pengaruh nyata $(\mathrm{p}<0,05)$ terhadap perlakuan overall kesukaan panelis.Rentang skala hedonik untuk parameter overall perlakuan To hingga $\mathrm{T}_{1}$ berkisar antara 2,84 3,68 dengan arah kesukaan yaitu biasa saja hingga suka dan perlakuan yang paling disuka yaitu T3.Hal ini diduga karena kelima parameter yaitu warna, aroma, tekstur, rasa dan kepulenan yang dihasilkan mengarah pada karakteristik beras umum yaitu beras padi sehingga $\mathrm{P}_{3}$ menjadi perlakuan yang disukai secara overall.

\section{SIMPULAN DAN SARAN}

\section{Simpulan}

Berdasarkan hasil penelitian yang telah dilakukan dapat disimpulkan bahwa penambahan tepung kacang merah di setiap perlakuan meningkatkan. kadar air, serat kasar, dan protein seiring dengan penambahan konsentrasi tepung kacang merah.Sedangkan dari segi sifat hedonik yang dilakukan, penambahan tepung kacang merah pada beras analog tidak meningkatkan kesukaan terhadap warna dan aroma namun untuk tekstur, rasa, kepulenan dan overall penambahan tepung kacang merah meningkatkan kesukaanpanelis terhadap beras analog. Penambahan tepung kacang merah paling tinggi konsentrasinya(15\%') merupakan beras analog dengan perlakuan terbaik ditinjau dari segi sifat kimia dan sifat hedonik.

\section{Saran}

Pada proses pengeringan beras analog menggunakan cahaya matahari untuk memperoleh kekeringan yang merata hingga ke bagian dalam sehingga tidak hanya mengeringdi permukaan saja, dan pembuatan tepung kacang merah dilakukan tanpa pengupasan kulit agar mengurangi bau langu yang ditimbulkan.

\section{DAFTAR RUJUKAN}

Adicandra, R. M. and Estiasih, T. (2016) 'Beras Analog dari ubi kelapa putih: Kajian Pustaka', Pangan dan Agroindustri.

Andriani, W. O. R. A., Ansharullah and Asyik, N. (2018) 'KARATERISTIK ORGANOLEPTIK DAN NILAI GIZI SNACK BAR BERBASIS TEPUNG BERAS MERAH (Oryza nivara) DAN TEPUNG JAGUNG (Zea mays L.) SEBAGAI MAKANAN SELINGAN TINGGI SERAT', Jurnal Sains dan Teknologi Pangan (JSTP).

Anggraeni, P. D., Darmanto, Y. S. and ... (2019) 'PENGARUH PENAMBAHAN NANOKALSIUM TULANG IKAN YANG BERBEDA TERHADAP KARAKTERISTIK BERAS ANALOG UMBI GEMBILI (Dioscorea esculenta) ...', Jurnal Ilmu dan ....

Astawan, M. (2009) Sehat dengan hidangan kacang dan bijibijian, Penebar Swadaya. 
Astuti, S. D. et al (2013) 'Formulasi dan Karakterisasi Cake Berbasis Tepung Komposit Organik Kacang Merah, Kedelai, dan Jagung)', Pembangunan Pedesaan.

Astuti, S., S., S. A. and Anayuka, S. A. (2019) 'Sifat Fisik dan Sensori Flakes Pati Garut dan Kacang Merah dengan Penambahan Tiwul Singkong', Jurnal Penelitian Pertanian Terapan. doi: 10.25181/jppt.v19i3.1440.

Bakhtra, D. D. A., Rusdi and Mardiah, A. (2016) 'PENETAPAN KADAR PROTEIN DALAM TELUR UNGGAS MELALUI ANALISIS NITROGEN MENGGUNAKAN METODE KJELDAHL', Jurnal Farmasi Higea. doi: 10.1159/o00301932.

Budi, F. S. et al. (2013) 'Teknologi Proses Ekstrusi untuk Membuat Beras Analog', Majalah Pangan. doi: $10.1021 /$ cmo50787y.

Ernawati, F., Prihatini, M. and Yuriestia, A. (2016) 'Gambaran Konsumsi Protein Nabati dan Hewani pada Anak Balita Stunting dan Gizi Kurang di Indonesia', Penelitian Gizi dan Makanan. doi: 10.22435/pgm.v39i2.6973.95-102.

'Karakterisasi Pati Ganyong (Canna edulis) dan Pemanfaatannya Sebagai Bahan Pembuatan Cookies dan Cendol' (2012) Karakterisasi Pati Ganyong (Canna edulis) dan Pemanfaatannya Sebagai Bahan Pembuatan Cookies dan Cendol. doi: 10.22146/agritech.9637.

Kusbandari, A. (2015) 'ANALISIS KUALITATIF KANDUNGAN SAKARIDA DALAM TEPUNG DAN PATI UMBI GANYONG (Canna edulis Ker.)', Pharmaciana. doi: 10.12928/pharmaciana.v5i1.2284.

Mahar Maligan, J., Dian Pratiwi, D. and Dewanti Widyaningsih, T. (2019) 'Studi Preferensi Konsumen terhadap Nasi Putih dan Nasi Jagung Putih pada Pekerja Wanita di Kantor Pemerintah Kota Malang', Indonesian Journal of Human Nutrition. doi: 10.21776/ub.ijhn.2019.006.01.5.

Masniawati, A. et al. (2012) 'Karakterisasi sifat fisikokimia beras merah pada beberapa sentra produksi beras di Sulawesi Selatan', Jurnal Jurusan Biologi.

Mentari, R., Anandito, R. B. K. and Basito (2016) 'Formulasi daging analog berbentuk bakso berbahan kacang merah (Phaseolus vulgaris) dan kacang kedelai (Glycine max)', Jurnal Teknosains Pangan.

Naga, W. S. et al. (2010) 'Koagulasi Protein dari Ekstrak Biji Kecipir dengan Metode Pemanasan', Jurnal Widya Teknik. doi: 10.33508/wt.v9i1.1292.

Pangastuti, H. A., Affandi, D. R. and Ishartani, D. (2013) 'Karakterisasi Sifat Fisik dan Kimia Tepung Kacang Merah (Phaseolus vulgaris L.) dengan Beberapa Perlakuan Pendahuluan', Jurnal Teknosains Pangan Januari Jurnal Teknosains Pangan.

Prawitasari, R. H., Ismadi, V. D. Y. B. and Estiningdriati, I. (2012) 'Kecernaan protein kasar dan serat kasar serta laju digesta pada ayam arab yang diberi ransum dengan berbagai level Azolla microphylla', Animal Agriculture Journal. doi: 10.1017/CBO9781107415324.004.

Rakhmawati, N., Amanto, B. S. and Praseptiaga, D. (2014) 'Formulasi Dan Evaluasi Sifat Sensor Dan Fisiokimia Produk Flakes Komposit Berbahan Dasar Tepung Tapioka, Tepung Kacang Merah (phaseolus vulgaris L.) Dan Tepung Konjac (Amorphophallus oncophillus)', Jurnal Teknologi Pangan.

Richana, N. and Sunarti, T. C. (2004) 'Karakterisasi Sifat
Fisikokimiatepung Umbi Dan Tepung Pati Dari Umbi Ganyong, Suweg, Ubikelapa Dan Gembili', J.Pascapanen.

Riskiani, D. et al. (2014) 'Pemanfaatan Tepung Umbi Ganyong (Canna edulis Ker.) sebagai Pengganti Tepung Terigu dalam Pembuatan Biskuit Tinggi Energi Protein dengan Penambahan Tepung Kacang Merah (Phaseolus Vulgaris L)', Jurnal Teknosains Pangan.

Srihari, E. et al. (2016) 'Rekayasa beras analog berbahan dasar campuran tepung talas, tepung maizena dan ubi jalar', Jurnal Teknik Kimia.

Sunyoto, M. (2017) 'KAJIAN SIFAT FUNGSIONAL DAN AMILOGRAFI PATI UBI JALAR (Ipomoea batatas L.) DENGAN PERLAKUAN SUHU DAN LAMA WAKTU HEAT MOISTURE TREATMENT SEBAGAI BAHAN SEDIAAN PANGAN DARURAT', JST (Jurnal Sains dan Teknologi). doi: 10.23887/jst-undiksha.v5i2.8824.

Trisnawati, M. I. and Nisa, F. C. (2015) 'Pengaruh Penambahan Konsentrat Protein Daun Kelor Dan Karagenan Terhadap Kualitas Mie Kering Tersubstitusi Mocaf', Pangan dan Agroindustri.

Wahjuningsih, S. B. (2019) 'KAJIAN INDEKS GLIKEMIK BERAS ANALOG BERBASIS TEPUNG MOKAF, TEPUNG GARUT DAN TEPUNG KACANG MERAH', JURNAL TEKNOLOGI DAN INDUSTRI PANGAN. doi: 10.33061/jitipari.v3i2.2698.

Wahjuningsih, S. B. and Kunarto, B. (2013) 'PEMBUATAN TEPUNG MOKAL DENGAN PENAMBAHAN BIANG FERMENTASI ALAMI UNTUK BERAS ANALOG', Jurnal Litbang Provinsi Jawa Tengah. doi: 10.1017/CBO9781107415324.004.

et al. (2013) 'PENGEMBANGAN BERAS ANALOG DENGAN MEMANFAATKAN JAGUNG PUTIH', Jurnal Teknologi dan Industri Pangan. doi: 10.6066/jtip.2013.24.2.194. 